\title{
Hormones removal from municipal wastewater using ultrasound
}

\author{
Aliakbar Roudbari ${ }^{1}$ and Mashallah Rezakazemi ${ }^{2 *}$ (i)
}

\begin{abstract}
Estrogens are one of the micro-pollutants in the wastewater which have detrimental effects on water living organisms. The aim of this study was to evaluate the efficiency of ultrasound to reduce the estrogen (E1) and 17 betaestradiol (E2) from municipal wastewater. Hence, a cylindrical batch reactor was designed. The effects of powers, frequency, exposure time and $\mathrm{pH}$ on reduction efficiency were investigated. The residual concentration of E1 and E2 hormones was measured in reactor effluent by electrochemiluminescence $(E C L)$ method. The results showed that ultrasound removed $85-96 \%$ of both E1 and E2 hormones after 45 min while other parameters changes in the range of their operations. Also, the frequency and power of ultrasound had a significant effect on reduction efficiency of hormones while the exposure had no significant effect. Furthermore, the interaction of power and frequency reduced their efficacy to $64.3 \%\left(P_{\text {value }}=0.005\right)$. The result also indicated that the ultrasound waves have high ability to reduce Steroid hormones from municipal wastewater. The proposed method can be considered as one of the significant strategies for reduction or destruction of hormones from wastewater due to the non-generation of dangerous byproducts and the low energy consumption.
\end{abstract}

Keywords: Estrogens, Ultrasound, Wastewater, Reduction, Hormones

\section{Introduction}

Estrogens are one of the micro-pollutants in wastewater which have detrimental effects on water living organisms (Azimi et al. 2017; Hamid and Eskicioglu 2012). These hormones are divided into five types: Progestin (Progesterone), Glucocorticosteroids (Cortisol), Mineral corticosteroids (Aldosterone), Androgen (Testosterone), and Estrogen (Nagarnaik et al. 2010). Estrone (E1) and 17 beta-estradiol (E2) are the most important estrogen hormones in wastewater which are excreted by all humans and animals (Guedes-Alonso et al. 2014). Estriol (E3) and 17-alpha-ethinyl estradiol (E4) are other estrogens which are found in smaller amounts in wastewater (Blair et al. 2013). The existence of these compounds in wastewater was firstly reported in 1965 (Hamid and Eskicioglu 2012) but was not seriously investigated by researchers until

\footnotetext{
*Correspondence: mashalah.rezakazemi@gmail.com; rezakazemi@shahroodut.ac.ir

${ }^{2}$ Faculty of Chemical and Materials Engineering, Shahrood University of Technology, Shahrood, Iran

Full list of author information is available at the end of the article
}

1980 that the detrimental impacts of these hormones were confirmed on fish growth (Behera et al. 2011). Steroid hormones are endocrine-disrupting compounds in the body which have become one of the major concerns as wastewater effluent in the environment because of negative effects on human health, animals, and ecosystem balance (Aker et al. 2016; Mendoza et al. 2016). Estrogen in very low concentrations (less than $0.1 \mathrm{ng} / \mathrm{L}$ ) interferes with reproduction of human, livestock, and wildlife and has a stimulatory effect on breast tumor growth (Ravindran et al. 2016). Some studies have shown its effect on uterine cancer, ovary and other cancers (Yi et al. 2016). These hormones either are produced naturally in the human and animal body or are found in some materials that humans deal with them on a daily basis. Detergents, shampoos, lotions, and cosmetics are new sources of these hormones in environment and wastewater.

The levels of estrogens are increasing in municipal and industrial wastewater due to increasing usage of these compounds (Cedat et al. 2016; González et al. 2015). Increasing the level of these substances in water resources and wastewater led to increasing attention of 
researchers and national and regional authorities to them and several studies have been conducted to determine their concentration in liquid environments. In a study in Brazil in 2012, E1 and E2 concentrations in raw wastewater were determined 566 and $143 \mathrm{ng} / \mathrm{L}$, respectively (Pessoa et al. 2014). Also, in the study on wastewater treatment lagoons in the US in 2011, the concentration of these hormones was reported 16.9 and $126 \mathrm{ng} / \mathrm{L}$, respectively (Luo et al. 2017). Also, the study conducted in South Korea in 2004 indicated E1 hormone levels in surface waters at $1 \mathrm{ng} / \mathrm{L}$ (Kim et al. 2007). Some of the studies on hormones are attributed to how to remove or decrease the amount of them in water resources and wastewater. Different methods are used in these studies; the most important methods are: activated sludge along with biological nutrient reduction (BNR) (Phillips et al. 2016) without reduction of biological nutrients (nBNR) (Sornalingam et al. 2016), oxidation ditch (Li et al. 2013), aeration lagoon ( $\mathrm{Li}$ and $\mathrm{Ni} 2011$ ), the combination of nanofiltration and reverse osmosis (Plósz et al. 2010), activated carbon adsorption (Foroutan et al. 2017; Furgal et al. 2015), peroxon process (Zhang et al. 2015), water chlorination and photo-Fenton-like degradation (Ifelebuegu et al. 2016). Wastewater treatment has been the subject of several recent studies (Baheri et al. 2014; Rezakazemi et al. 2018b; Muhammad et al. 2017; Rezakazemi 2018; Rezakazemi et al. 2011a, b, 2012, 2013, 2014; Rezakazemi et al. 2018a, c; Shahverdi et al. 2013; Shirazian et al. 2012). Indeed, the efficiency of these methods for reducing the hormones is different and some of them were unable to provide acceptable reduction efficacy (Wojnarowicz et al. 2014). According to studies, biological treatment methods and advanced treatment processes have better ability to remove or reduce the amount of hormones. Although biological treatment can eliminate hormones, some hormones remain in the effluent (Auriol et al. 2008). Advanced treatment methods have higher ability to remove hormone, but they are faced with two limitations of high costs and dangerous by-products formation (Moreira et al. 2017).

In general, most of the methods proposed for the removal of hormones are on a laboratory scale and there are few real scale examples. One of the most effective methods to remove hormones without by-products generation is ultrasound (waves with a frequency greater than $20 \mathrm{kHz}$ ). Ultrasound waves which had discovered by Francis Galton in 1876 are produced by two methods: Piezoelectricity (interaction of mechanical pressure and electrical power), and Magnetostriction (Generation of ultrasonic waves in the electromagnetic field) (Musielak et al. 2016). This method is used for remedy of new injuries and old and chronic inflammations, recovery of elastic skin and reduction of organic chemical pollutants from liquid environments (Mahravan et al. 2016).

The aim of this study was to investigate the effect of ultrasound on the reduction of sewage hormones from wastewater and not effluent. To achieve this purpose, samples were taken from the end of wastewater collection network before entering the first unit of the treatment plant. Investigations showed that very few studies have been done on the effects of ultrasound on reducing hormones parameters such as the effect of power and different frequencies, the effect of exposure time to ultrasound, the effect of initial $\mathrm{pH}$, and also the interaction of ultrasound frequency and power. Therefore, the aim of this study was to investigate the effect of power, frequency, exposure time, initial $\mathrm{pH}$, and also the interaction of ultrasound frequency and power on reduction efficiency of Estrone and 17 beta-Estradiol from municipal wastewater. Moreover, the main aspects of this technology have not been studied yet.

\section{Materials and methods Chemicals}

All required chemicals including ferrous sulfate, sulfuric acid, and hydrogen peroxide were purchased from Sigma-Aldrich. In this study, E1 and E2 hormones were studied. The existence of these hormones in wastewater with higher concentrations than other hormones, as well as differences in chemical structure, molecular weight, and their properties were the reasons for choosing these two hormones. The concentrations of these hormones in wastewater were between 485 and $535 \mathrm{ng} / \mathrm{L}$. Sulfuric acid was used to adjust $\mathrm{pH}$. Ferrous sulfate and hydrogen peroxide were used for sample preparation in ECL method.

\section{Wastewater characteristics and preliminary experiments}

Wastewater used in this study was prepared from Shahrood wastewater treatment plant. This treatment plant uses stabilization ponds process and is the largest treatment plant in Semnan province. Samples were taken from the entry of the first pond. The characteristics of wastewater are described in Table 1 . Samples after collecting were tested immediately to minimize biochemical changes. The amount of nitrogen ammonia and $\mathrm{pH}$ were

\section{Table 1 Characteristics of wastewater}

\begin{tabular}{llllll}
\hline Parameter & Value & Unit & Parameter & Value & UNIT \\
\hline Total solids & $1150 \pm 65$ & $\mathrm{mg} / \mathrm{L}$ & TOC & $156 \pm 16$ & $\mathrm{mg} / \mathrm{L}$ \\
COD & $340 \pm 48$ & $\mathrm{mg} / \mathrm{L}$ & $\mathrm{pH}$ & $7.2 \pm 0.35$ & - \\
BOD & $225 \pm 43$ & $\mathrm{mg} / \mathrm{L}$ & Ammonia nitro- & $652 \pm 34$ & $\mathrm{mg} / \mathrm{L}$ \\
& & & gen & & \\
E1 & $485 \pm 32$ & $\mathrm{ng} / \mathrm{L}$ & E2 & $511 \pm 16$ & $\mathrm{ng} / \mathrm{L}$ \\
\hline
\end{tabular}


measured by C203 8 parameter test meter device (Hanna Electronics Company) and benchtop pH meters (ColeParmer Co., Ltd Company). The $\mathrm{pH}$ meter was calibrated before each use with $\mathrm{pH} 3,7$ and 10 buffer solutions. The biochemical oxygen demand (BOD) and chemical oxygen demand (COD) measurements were determined following Standard Methods 5210 and 5220, respectively. Total solids (TS) were measured through evaporation in a furnace at $105^{\circ} \mathrm{C}$ for $1 \mathrm{~h}$.

\section{Reactor characteristics}

In this study, a cylindrical reactor made of Plexiglas in the amount of $1.5 \mathrm{~L}$ for the batch reactor was designed (Fig. 1). The reactor contents were stirred by a stirrer magnet with low speed $(450 \mathrm{rpm})$. The source of ultrasound generation was the device Model UGMA-5000 (Sonotek Company) with three transducers 30, 45 and $60 \mathrm{kHz}$ equipped with a titanium probe with a diameter of $20 \mathrm{~mm}$, operated over a frequency range of $25-250 \mathrm{kHz}$ with a display resolution of 0.01 Watts and $\pm 4 \%$ accuracy leading for increased repeatability. The probe submerging depth in the reactor was $22.5 \mathrm{~cm}$ (half of the reactor depth).

\section{Experimental setup}

In this study, the effect of ultrasound power, frequency and exposure time and also the initial $\mathrm{pH}$ of wastewater on the reduction of E1 and E2 hormones were investigated. For this purpose, the effect of powers (70 and $110 \mathrm{~W})$, frequency $(30,45$ and $60 \mathrm{kHz})$, exposure time (30, 60, 90 and $120 \mathrm{~min})$ and $\mathrm{pH}(3,7$ and 10$)$ were

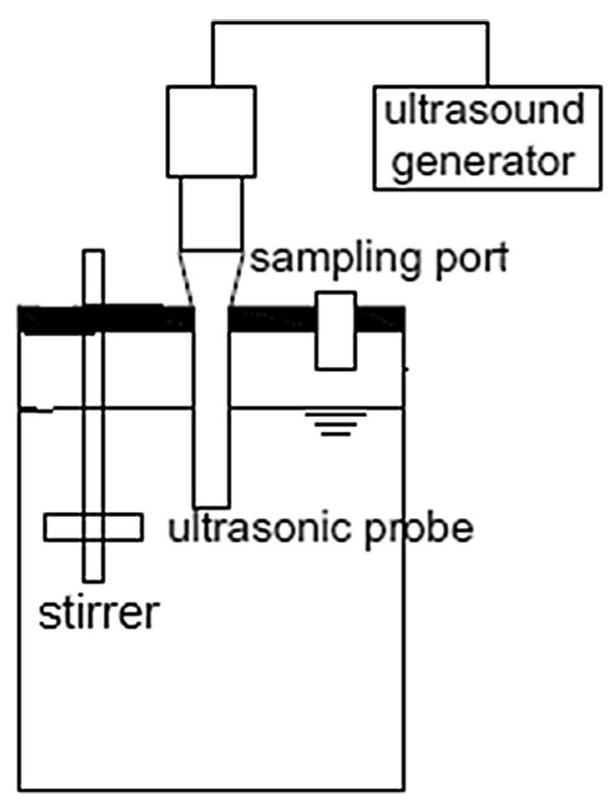

Fig. 1 Schematic of reactor investigated. Also, each test was repeated 3 times, and residual concentration of E1 and E2 hormones was measured in the reactor effluent.

\section{Analytical method}

Hormone concentration was measured by electroluminescence (ECL) method (Kische et al. 2016). For this purpose, the joint product of Roche and Hitachi, Elecsys 2010, was used. In this method, $35 \mu \mathrm{L}$ of the sample with a specific estradiol antibody constitute an immune complex. Then the tiny spherical constituents coated with streptavidin are added to the environment that consequently, places of antibodies that are still empty can form an antibody mixture (Hapten) and are filled with it. Then, all mixture transferred to a solid phase during an interaction and being pulled into measuring cell. In this cell, micron particles magnetically trapped on the electrode surface and substances that have not been trapped will be removed by Procell. Then voltage is added to the electrode to cause emission of chemiluminescence light. The amount of the light is measured by a light multiplier. Then, the result is taken to the calibration curve and the amount of hormones was determined (Cacho et al. 2016). A detection limit of ECL was adjusted to $1-500 \mathrm{ng} / \mathrm{L}$.

\section{Statistical analysis}

In this study, the effects of frequency, power, exposure time, and initial $\mathrm{pH}$ were evaluated on the amount of the E1 and E2 reduction from municipal wastewater. SPSS version 19 was used for statistical analysis. One way ANOVA was used for evaluating the effect of frequency, exposure time and $\mathrm{pH}$ and Independent Sample $T$ Test was used for evaluating the effect of power. Tukey HSD was used to determine which value of the variable was effective to remove hormones. Univariate analysis was used to evaluate the effect of interaction and Levene test is used to determine the equal or unequal variances in different groups for each variable. When the variances in different groups were not being equal, Kruskal-Wallis test (its nonparametric equivalent) and Mann-Whitney test were used instead of one-way ANOVA and independent sample $T$-Test, respectively.

\section{Results}

Table 1 shows the wastewater characteristics which were used in the study. As can be seen, the wastewater was clearly representative of municipal wastewaters. The studies performed by Sun et al. (2016) and Renuka et al. (2016) showed similar results. The results showed that ultrasound waves had the high ability on reducing hormones E1 and E2 (Tables 2 and 3). Figure 2 shows the effect of power on E1 and E2 reduction. As can be seen, with increasing the ultrasound power increases 
Table 2 Reduction rate (\%) of estrogen by ultrasound at different time, power, pH and frequency (Mean \pm SD)

\begin{tabular}{|c|c|c|c|c|c|c|}
\hline \multirow[t]{2}{*}{$\mathrm{pH}$} & \multirow[t]{2}{*}{ Power (W) } & \multirow[t]{2}{*}{ Frequency (KHz) } & \multicolumn{4}{|c|}{ Time (min) } \\
\hline & & & 30 & 60 & 90 & 120 \\
\hline 3 & 70 & 30 & $12.4 \pm 2.3$ & $12.7 \pm 1.4$ & $13.1 \pm 1.3$ & $13.2 \pm 1.3$ \\
\hline 3 & 70 & 45 & $13.3 \pm 1.8$ & $13.5 \pm 1.6$ & $13.8 \pm 1.2$ & $14.5 \pm 1.2$ \\
\hline 3 & 70 & 60 & $14.3 \pm 1.3$ & $15.6 \pm 1.4$ & $15.8 \pm 1.2$ & $16.5 \pm 1.3$ \\
\hline 3 & 110 & 30 & $20.5 \pm 2.4$ & $21.1 \pm 2.1$ & $21.5 \pm 1.7$ & $21.9 \pm 1.6$ \\
\hline 3 & 110 & 45 & $22.3 \pm 1.5$ & $22.7 \pm 1.5$ & $22.9 \pm 1.4$ & $23.3 \pm 1.1$ \\
\hline 3 & 110 & 60 & $23.5 \pm 1.2$ & $23.7 \pm 1.2$ & $24.1 \pm 1.4$ & $24.3 \pm 1.2$ \\
\hline 7 & 70 & 30 & $26.3 \pm 1.4$ & $26.7 \pm 1.2$ & $29.6 \pm 1.5$ & $31.2 \pm 1.4$ \\
\hline 7 & 70 & 45 & $32.5 \pm 1.2$ & $32.3 \pm 1.1$ & $33.8 \pm 1.3$ & $35.2 \pm 1.6$ \\
\hline 7 & 70 & 60 & $31.5 \pm 1.3$ & $33.1 \pm 1.2$ & $35.6 \pm 1.2$ & $38.9 \pm 1.8$ \\
\hline 7 & 110 & 30 & $39.1 \pm 2.5$ & $40.5 \pm 2.9$ & $40.8 \pm 2.3$ & $42.3 \pm 3.1$ \\
\hline 7 & 110 & 45 & $42.1 \pm 3.2$ & $43.5 \pm 2.7$ & $44.9 \pm 2.6$ & $46.1 \pm 2.5$ \\
\hline 7 & 110 & 60 & $46.0 \pm 2.5$ & $46.1 \pm 2.8$ & $47.8 \pm 2.6$ & $49.2 \pm 2.5$ \\
\hline 10 & 70 & 30 & $67.1 \pm 3.1$ & $68.9 \pm 3.6$ & $69.5 \pm 2.7$ & $70.6 \pm 2.8$ \\
\hline 10 & 70 & 45 & $70.8 \pm 2.6$ & $71.5 \pm 2.5$ & $74.2 \pm 2.7$ & $75.3 \pm 2.6$ \\
\hline 10 & 70 & 60 & $75.6 \pm 2.5$ & $75.9 \pm 2.6$ & $77.5 \pm 2.8$ & $79.6 \pm 2.6$ \\
\hline 10 & 110 & 30 & $81.3 \pm 2.6$ & $81.9 \pm 2.5$ & $82.6 \pm 3.1$ & $84.6 \pm 3.1$ \\
\hline 10 & 110 & 45 & $85.8 \pm 3.7$ & $86.9 \pm 2.6$ & $87.2 \pm 3.5$ & $90.9 \pm 3.2$ \\
\hline 10 & 110 & 60 & $91.1 \pm 3.1$ & $91.2 \pm 3.1$ & $92.2 \pm 3.2$ & $94.2 \pm 2.7$ \\
\hline
\end{tabular}

Table 3 Reduction rate (\%) of 17 beta-estradiol by ultrasound at different time, power, pH and frequency (Mean \pm SD)

\begin{tabular}{|c|c|c|c|c|c|c|}
\hline \multirow[t]{2}{*}{$\mathrm{pH}$} & \multirow[t]{2}{*}{ Power (W) } & \multirow[t]{2}{*}{ Frequency $(\mathrm{KHz})$} & \multicolumn{4}{|c|}{ Time (min) } \\
\hline & & & 30 & 60 & 90 & 120 \\
\hline 3 & 70 & 30 & $12.2 \pm 1.8$ & $12.5 \pm 1.6$ & $13.0 \pm 1.1$ & $13.1 \pm 1.3$ \\
\hline 3 & 70 & 45 & $13.1 \pm 1.2$ & $13.2 \pm 1.3$ & $13.3 \pm 1.2$ & $13.7 \pm 1.4$ \\
\hline 3 & 70 & 60 & $13.8 \pm 1.1$ & $14.5 \pm 1.2$ & $15.1 \pm 1.2$ & $15.8 \pm 1.1$ \\
\hline 3 & 110 & 30 & $19.8 \pm 1.3$ & $21.0 \pm 1.3$ & $21.2 \pm 1.2$ & $21.6 \pm 1.4$ \\
\hline 3 & 110 & 45 & $21.9 \pm 1.3$ & $22.3 \pm 1.2$ & $22.5 \pm 1.4$ & $23.1 \pm 1.4$ \\
\hline 3 & 110 & 60 & $23.1 \pm 1.4$ & $23.5 \pm 1.4$ & $24.0 \pm 1.3$ & $24.1 \pm 1.4$ \\
\hline 7 & 70 & 30 & $25.8 \pm 1.6$ & $26.4 \pm 1.5$ & $28.8 \pm 1.5$ & $30.8 \pm 1.3$ \\
\hline 7 & 70 & 45 & $31.8 \pm 1.2$ & $32.1 \pm 1.3$ & $32.5 \pm 1.2$ & $34.5 \pm 1.2$ \\
\hline 7 & 70 & 60 & $30.8 \pm 1.3$ & $32.5 \pm 1.2$ & $34.2 \pm 1.4$ & $37.5 \pm 1.6$ \\
\hline 7 & 110 & 30 & $38.6 \pm 1.3$ & $39.8 \pm 1.2$ & $40.5 \pm 1.2$ & $41.8 \pm 1.4$ \\
\hline 7 & 110 & 45 & $41.8 \pm 1.3$ & $42.9 \pm 1.4$ & $44.5 \pm 1.3$ & $45.8 \pm 1.4$ \\
\hline 7 & 110 & 60 & $43.0 \pm 1.2$ & $45.6 \pm 1.4$ & $46.2 \pm 1.3$ & $48.2 \pm 1.5$ \\
\hline 10 & 70 & 30 & $66.5 \pm 2.3$ & $67.8 \pm 2.1$ & $69.2 \pm 2.2$ & $70.8 \pm 2.3$ \\
\hline 10 & 70 & 45 & $70.9 \pm 2.4$ & $72.3 \pm 2.2$ & $74.2 \pm 2.3$ & $75.5 \pm 2.1$ \\
\hline 10 & 70 & 60 & $75.3 \pm 2.2$ & $75.9 \pm 2.1$ & $76.8 \pm 2.3$ & $78.5 \pm 2.1$ \\
\hline 10 & 110 & 30 & $81.9 \pm 2.4$ & $82.3 \pm 2.3$ & $82.5 \pm 2.8$ & $83.9 \pm 2.6$ \\
\hline 10 & 110 & 45 & $86.2 \pm 2.5$ & $86.9 \pm 2.6$ & $86.6 \pm 2.8$ & $88.9 \pm 2.6$ \\
\hline 10 & 110 & 60 & $90.9 \pm 2.4$ & $91.3 \pm 2.5$ & $91.8 \pm 2.3$ & $93.6 \pm 2.2$ \\
\hline
\end{tabular}

the efficacy reduction of E1 and E2. Figure 3 shows the effect of frequency on E1 and E2 reduction. As can be seen, with increasing ultrasound frequency, the reduction efficacy of E1 and E2 has increased. Figure 4 shows the effect of exposure time on E1 and E2 reduction. As can be seen, with increasing exposure time, the reduction efficacy of E1 and E2 somewhat has increased but the not significant. Figure 5 shows the effect of $\mathrm{pH}$ on E1 and E2 


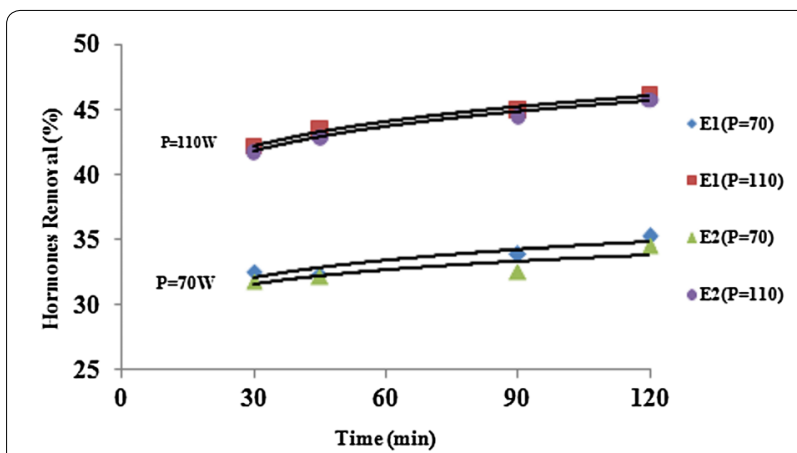

Fig. 2 Effect of power on E1 and E2 reduction (frequency $=45 \mathrm{kHz}$, $\mathrm{pH} 7$ )

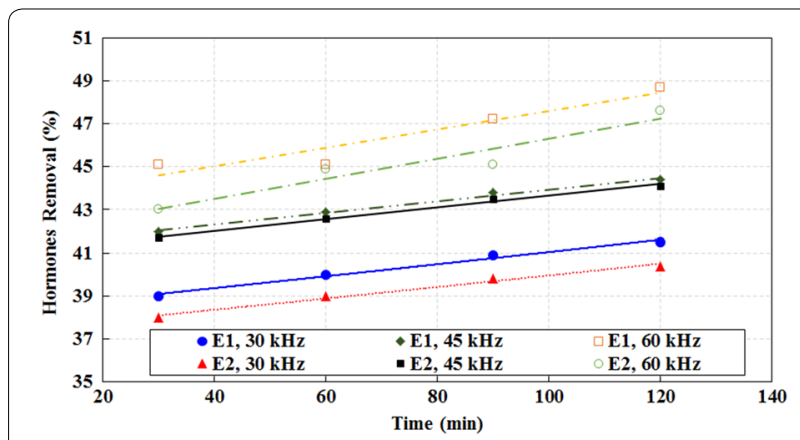

Fig. 3 Effect of frequency on E1 and E2 reduction (power $=70, \mathrm{pH} 7$ )

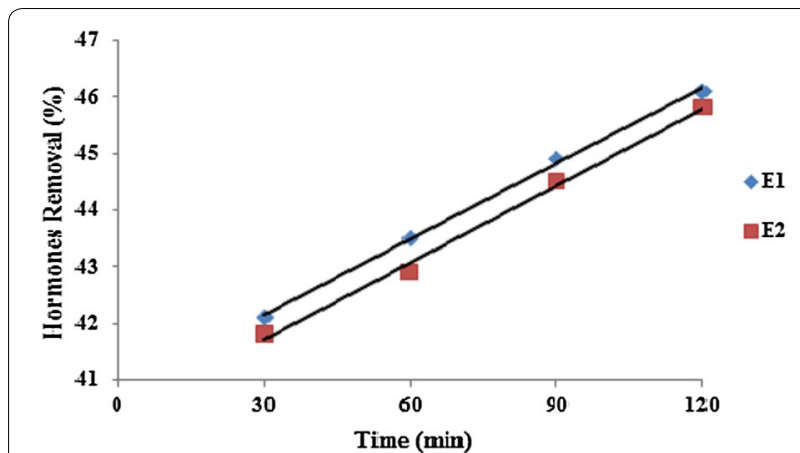

Fig. 4 Effect of exposure time on E1 and E2 reduction (power $=110$, frequency $=60 \mathrm{kHz}$ )

reduction. As can be seen, with increasing $\mathrm{pH}$, the reduction efficacy of E1 and E2 has increased.

\section{Discussion}

In this study, the effect of power, frequency, exposure time, initial $\mathrm{pH}$, and also the concurrent effect of power and frequency on Estrone and 17 beta-Estradiol reduction from municipal wastewater were investigated. According to the results, ultrasound can reduce 85-96\%

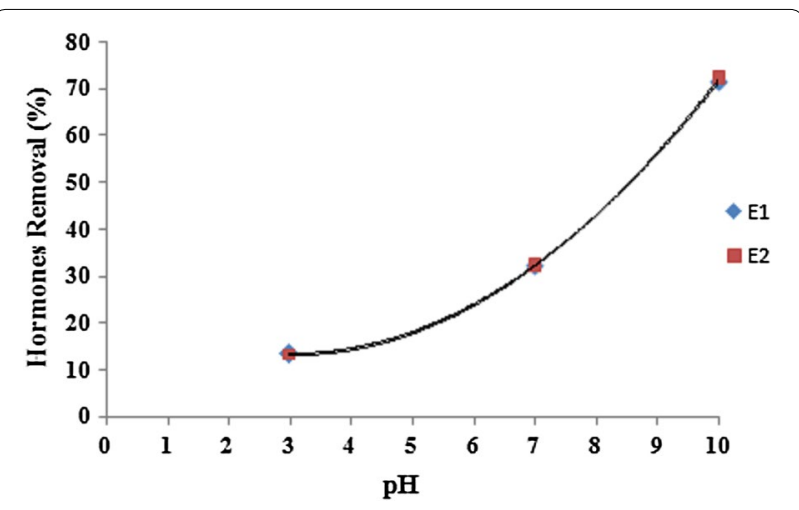

Fig. 5 Effect of pH on E1 and E2 reduction (power $=110$, frequency $=60 \mathrm{kHz}$ )

of E1 and E2 after 45 min while other parameters changes in the range of their operations and ultrasound frequency and power had a significant effect on reduction efficiency but exposure time had no significant effect. Also despite the fact that the power and frequency individually had a significant effect on hormones reduction, but their concurrent effect was reductive. With the increasing initial $\mathrm{pH}$, reduction efficacy increased due to the increased production of hydroxyl radicals. The result indicated that the ultrasound has high ability to remove Steroid hormones from municipal wastewater, so due to nongeneration of dangerous by-products and low electricity requirement; this method can be considered as a valuable strategy for reduction or destruction of hormones from water resources.

The effect of frequency and power on reducing E1 and E2 was significant but the effect of exposure time was not significant. Statistical analysis of Univariate showed that the power individually had effective rates of 89.9 and $90.1 \%$ on E1 and E2 reduction, respectively, and the frequency individually had effective rates of 80.1 and $82.2 \%$ on E1 and E2 reduction, respectively. But the concurrent effect of frequency and power was significant $\left(\mathrm{P}_{\text {value }}\right.$ for E1 and E2 were 0.008 and 0.006, respectively) and decreases (reduction efficacy for E1 and E2 were 68.5 and $70.1 \%$, respectively).

In fact, ultrasound waves lead to extensive destruction of organic materials, particularly macromolecules and massive organic materials by the formation of hydroxyl radical and cavitations phenomenon (Budiman and Wu 2016; Wu et al. 2012). E1 and E2 hormones have strong oxidizing properties, so they are easily oxidized by hydroxyl free radicals produced by ultrasound (Renuka et al. 2016). Also, these compounds are exposed to cavitation (Hotspot) made by ultrasound and they will remove because they have carbon ring of cyclohexane and cyclopentane types and desirable volatility properties (Jia et al. 2015). Andaluri et al. (2012) in a study 
showed that ultrasound can destruct some hormones through the production of hydroxyl radical and cavitation phenomenon.

According to Sono-chemical theory, when the ultrasound power increases more than the cavitations threshold, bubbles are formed faster and more and release its energy easily (Andaluri et al. 2012), so a large number of cavitations bubbles explode with high energy in a short time and destroy hormonal molecules attached to themselves, thus the efficiency of hormones reduction increases. Statistical analysis of independent sample T-Test showed that there is a significant difference between $\mathrm{E} 1$ and $\mathrm{E} 2$ concentrations in different powers in reactor influent and effluent $\left(\mathrm{P}_{\text {value }}=0.001\right.$ for both hormones). The results of the study are consistent with the study of Andaluri et al. (2012). They studied ultrasonic oxidation of diethyl phthalate and concluded that with increasing the power, the removal efficacy increases.

The increasing of frequency leads to increasing the number of cavitations bubbles and also the number of hydroxyl radicals in the environment (Suri et al. 2007), so the reduction efficacy of E1 and E2 increases. The statistical analysis of one way ANOVA showed that there is a significant difference between E1 and E2 concentrations in different frequencies in reactor influent and effluent ( $\mathrm{P}_{\text {value }}$ for E1 and E2 are 0.001 and 0.002 respectively). Also, statistical analysis of Tukey showed there is a significant difference between 30 and $60 \mathrm{kHz}$ frequencies ( $\mathrm{P}_{\text {value }}$ for $\mathrm{E} 1$ and $\mathrm{E} 2$ are 0.001 and 0.002 , respectively) and between 45 and $60 \mathrm{kHz}$ frequencies ( $\mathrm{P}_{\text {value }}$ for $\mathrm{E} 1$ and $\mathrm{E} 2$ are 0.002 and 0.001 , respectively) on E1 and E2 reduction. Suri et al. (2007) confirmed the effect of frequency on hormones reduction in their study.

In fact, because the formation of hydroxyl radical and cavitations bubbles begin to operate in very short time, hence with increasing exposure time, the reduction efficiency will increase slightly (Selvaraj et al. 2015), in another word the majority of these hormones are removed in early times. Also, the statistical analysis of one-way ANOVA showed there is no significant difference between E1 and E2 concentrations in reactor influent and effluent at different exposure times $\left(\mathrm{P}_{\text {value }}\right.$ for $\mathrm{E} 1$ and $\mathrm{E} 2$ are 0.17 and 0.21 , respectively).

With increasing $\mathrm{pH}$, the number of hydroxyl radicals produced in the environment is increased (Okada et al. 2009) and consequently the rate of oxidation and hormone reduction increases, so as can be seen from Fig. 5 the alkaline environment increases hormones reduction. Statistical analysis of one way ANOVA showed there is a significant difference between E1 and E2 concentrations in reactor influent and effluent at different $\mathrm{pH}\left(\mathrm{P}_{\text {value }}\right.$ for $\mathrm{E} 1$ and $\mathrm{E} 2$ are 0.17 and 0.21 , respectively).

\section{Authors' contributions}

The work is a product of the intellectual environment of the whole team; and that all members have contributed in various degrees to the analytical methods used, to the research concept, and to the experiment design. All authors read and approved the final manuscript.

\section{Author details}

${ }^{1}$ Center for Social and Behavioral Sciences Research, Shahroud University of Medical Sciences, Shahroud, Iran. ${ }^{2}$ Faculty of Chemical and Materials Engineering, Shahrood University of Technology, Shahrood, Iran.

\section{Acknowledgements}

Not applicable.

Competing interests

The authors declare that they have no competing interests.

Availability of data and materials

The datasets generated and/or analysed during the current study are available from the corresponding author on reasonable request.

\section{Consent for publication}

Not applicable.

Ethics approval and consent to participate

Not applicable.

Funding

Not applicable.

\section{Publisher's Note}

Springer Nature remains neutral with regard to jurisdictional claims in published maps and institutional affiliations.

Received: 5 April 2018 Accepted: 23 May 2018

Published online: 01 June 2018

\section{References}

Aker AM, Watkins DJ, Johns LE, Ferguson KK, Soldin OP, Del Toro LVA, Alshawabkeh AN, Cordero JF, Meeker JD (2016) Phenols and parabens in relation to reproductive and thyroid hormones in pregnant women. Environ Res 151:30-37

Andaluri G, Rokhina EV, Suri RPS (2012) Evaluation of relative importance of ultrasound reactor parameters for the removal of estrogen hormones in water. Ultrason Sonochem 19:953-958. https://doi.org/10.1016/j.ultso nch.2011.12.005

Auriol M, Filali-Meknassi Y, Adams CD, Tyagi RD, Noguerol T-N, Piña B (2008) Removal of estrogenic activity of natural and synthetic hormones from a municipal wastewater: efficiency of horseradish peroxidase and laccase from Trametes versicolor. Chemosphere 70:445-452. https://doi. org/10.1016/j.chemosphere.2007.06.064

Azimi A, Azari A, Rezakazemi M, Ansarpour M (2017) Removal of heavy metals from industrial wastewaters: a review. ChemBioEng Reviews 4:37-59. https://doi.org/10.1002/cben.201600010

Baheri B, Shahverdi M, Rezakazemi M, Motaee E, Mohammadi T (2014) Performance of PVA/NaA mixed matrix membrane for removal of water from ethylene glycol solutions by pervaporation. Chem Eng Commun 202:316-321. https://doi.org/10.1080/00986445.2013.841149

Behera SK, Kim HW, Oh J-E, Park H-S (2011) Occurrence and removal of antibiotics, hormones and several other pharmaceuticals in wastewater treatment plants of the largest industrial city of Korea. Sci Total Environ 409:4351-4360. https://doi.org/10.1016/j.scitotenv.2011.07.015

Blair BD, Crago JP, Hedman CJ, Treguer RJF, Magruder C, Royer LS, Klaper RD (2013) Evaluation of a model for the removal of pharmaceuticals, personal care products, and hormones from wastewater. Sci Total Environ 444:515-521. https://doi.org/10.1016/j.scitotenv.2012.11.103

Budiman PM, Wu TY (2016) Ultrasonication pre-treatment of combined effluents from palm oil, pulp and paper mills for improving photofermentative 
biohydrogen production. Energy Convers Manage 119:142-150. https:// doi.org/10.1016/j.enconman.2016.03.060

Cacho Jl, Campillo N, Viñas P, Hernández-Córdoba M (2016) Evaluation of the contamination of spirits by polycyclic aromatic hydrocarbons using ultrasound-assisted emulsification microextraction coupled to gas chromatography-mass spectrometry. Food Chem 190:324-330. https://doi. org/10.1016/j.foodchem.2015.05.106

Cedat B, de Brauer C, Metivier H, Dumont N, Tutundjan R (2016) Are UV photolysis and $\mathrm{UV} / \mathrm{H} 2 \mathrm{O} 2$ process efficient to treat estrogens in waters? Chemical and biological assessment at pilot scale. Water Res 100:357366. https://doi.org/10.1016/j.watres.2016.05.040

Foroutan R, Esmaeili H, Abbasi M, Rezakazemi M, Mesbah M (2017) Adsorption behavior of $\mathrm{Cu}(\mathrm{II})$ and $\mathrm{Co}(\mathrm{II})$ using chemically modified marine algae. Environ Technol. https://doi.org/10.1080/09593330.2017.1365946

Furgal KM, Meyer RL, Bester K (2015) Removing selected steroid hormones, biocides and pharmaceuticals from water by means of biogenic manganese oxide nanoparticles in situ at ppb levels. Chemosphere 136:321326. https://doi.org/10.1016/j.chemosphere.2014.11.059

González A, Avivar J, Cerdà V (2015) Estrogens determination in wastewater samples by automatic in-syringe dispersive liquid-liquid microextraction prior silylation and gas chromatography. J Chromatogr A 1413:1-8. https ://doi.org/10.1016/j.chroma.2015.08.031

Guedes-Alonso R, Montesdeoca-Esponda S, Sosa-Ferrera Z, Santana-Rodríguez JJ (2014) Liquid chromatography methodologies for the determination of steroid hormones in aquatic environmental systems. Trends Environ Anal Chem 3:14-27. https://doi.org/10.1016/j.teac.2014.10.001

Hamid H, Eskicioglu C (2012) Fate of estrogenic hormones in wastewater and sludge treatment: a review of properties and analytical detection techniques in sludge matrix. Water Res 46:5813-5833. https://doi. org/10.1016/j.watres.2012.08.002

Ifelebuegu AO, Ukpebor J, Nzeribe-Nwedo B (2016) Mechanistic evaluation and reaction pathway of UV photo-assisted Fenton-like degradation of progesterone in water and wastewater. Int J Environ Sci Technol 13:2757-2766. https://doi.org/10.1007/s13762-016-1103-3

Jia S, Han H, Hou B, Zhuang H (2015) Advanced treatment of biologically pretreated coal gasification wastewater by a novel integration of threedimensional catalytic electro-Fenton and membrane bioreactor. Bioresour Technol 198:918-921. https://doi.org/10.1016/j.biortech.2015.09.080

Kim SD, Cho J, Kim IS, Vanderford BJ, Snyder SA (2007) Occurrence and removal of pharmaceuticals and endocrine disruptors in South Korean surface, drinking, and waste waters. Water Res 41:1013-1021. https://doi. org/10.1016/j.watres.2006.06.034

Kische H, Gross S, Wallaschofski H, Volzke H, Dorr M, Nauck M, Haring R (2016) Clinical correlates of sex hormones in women: the study of health in Pomerania. Metab Clin Exp 65:1286-1296. https://doi.org/10.1016/j. metabol.2016.05.011

Li H, Ni J (2011) Treatment of wastewater from Dioscorea zingiberensis tubers used for producing steroid hormones in a microbial fuel cell. Bioresour Technol 102:2731-2735. https://doi.org/10.1016/j.biortech.2010.11.030

Li X, Zheng W, Kelly WR (2013) Occurrence and removal of pharmaceutical and hormone contaminants in rural wastewater treatment lagoons. Sci Total Environ 445-446:22-28. https://doi.org/10.1016/j.scitotenv.2012.12.035

Luo X, Cao J, He L, Wang H, Yan H, Qin Y (2017) An experimental study on the coalescence process of binary droplets in oil under ultrasonic standing waves. Ultrason Sonochem 34:839-846. https://doi.org/10.1016/j.ultso nch.2016.07.024

Mahravan E, Naderan H, Damangir E (2016) Frequency and wavelength prediction of ultrasonic induced liquid surface waves. Ultrasonics 72:184-190. https://doi.org/10.1016/j.ultras.2016.08.002

Mendoza C, Barreto GE, Ávila-Rodriguez M, Echeverria V (2016) Role of neuroinflammation and sex hormones in war-related PTSD. Mol Cell Endocrinol 434:266-277. https://doi.org/10.1016/.mce.2016.05.016

Moreira FC, Boaventura RAR, Brillas E, Vilar VJP (2017) Electrochemical advanced oxidation processes: a review on their application to synthetic and real wastewaters. Appl Catal B 202:217-261. https://doi. org/10.1016/j.apcatb.2016.08.037

Muhammad A, Younas M, Rezakazemi M (2017) Quasi-dynamic modeling of dispersion-free extraction of aroma compounds using hollow fiber membrane contactor. Chem Eng Res Des 127:52-61. https://doi.org/10.1016/j. cherd.2017.09.007
Musielak G, Mierzwa D, Kroehnke J (2016) Food drying enhancement by ultrasound - review. Trends Food Sci Technol 56:126-141. https://doi. org/10.1016/j.tifs.2016.08.003

Nagarnaik PM, Mills MA, Boulanger B (2010) Concentrations and mass loadings of hormones, alkylphenols, and alkylphenol ethoxylates in healthcare facility wastewaters. Chemosphere 78:1056-1062. https://doi. org/10.1016/j.chemosphere.2009.11.019

Okada K, Kudo N, Hassan MA, Kondo T, Yamamoto K (2009) Threshold curves obtained under various gaseous conditions for free radical generation by burst ultrasound-Effects of dissolved gas, microbubbles and gas transport from the air. Ultrason Sonochem 16:512-518. https://doi. org/10.1016/j.ultsonch.2008.11.010

Pessoa GP, de Souza NC, Vidal CB, Alves JAC, Firmino PIM, Nascimento RF, dos Santos AB (2014) Occurrence and removal of estrogens in Brazilian wastewater treatment plants. Sci Total Environ 490:288-295. https://doi. org/10.1016/j.scitotenv.2014.05.008

Phillips P, Gibson CA, Fisher SC, Fisher I, Reilly TJ, Smalling KL, Romanok KM, Foreman WT, ReVello RC, Focazio MJ, Jones DK (2016) Regional variability in bed-sediment concentrations of wastewater compounds, hormones and PAHs for portions of coastal New York and New Jersey impacted by hurricane Sandy. Mar Pollut Bull 107:489-498. https://doi.org/10.1016/j. marpolbul.2016.04.050

Plósz BG, Leknes H, Liltved H, Thomas KV (2010) Diurnal variations in the occurrence and the fate of hormones and antibiotics in activated sludge wastewater treatment in Oslo, Norway. Sci Total Environ 408:1915-1924. https://doi.org/10.1016/j.scitotenv.2010.01.042

Ravindran B, Wong JWC, Selvam A, Sekaran G (2016) Influence of microbial diversity and plant growth hormones in compost and vermicompost from fermented tannery waste. Bioresour Technol 217:200-204. https:// doi.org/10.1016/j.biortech.2016.03.032

Renuka R, Mohan SM, Sowmiya B, Raj SA (2016) Performance evaluation of panelled anaerobic baffle-cum-filter reactor in treating municipal wastewater. Ecol Eng 97:1-12. https://doi.org/10.1016/j.ecoleng.2016.07.020

Rezakazemi M (2018) CFD simulation of seawater purification using direct contact membrane desalination (DCMD) system. Desalination. https:// doi.org/10.1016/j.desal.2017.12.048

Rezakazemi M, Razavi S, Mohammadi T, Nazari AG (2011a) Simulation and determination of optimum conditions of pervaporative dehydration of isopropanol process using synthesized PVA-APTEOS/TEOS nanocomposite membranes by means of expert systems. J Membr Sci 379:224-232. https://doi.org/10.1016/j.memsci.2011.05.070

Rezakazemi M, Shahverdi M, Shirazian S, Mohammadi T, Pak A (2011b) CFD simulation of water removal from water/ethylene glycol mixtures by pervaporation. Chem Eng J 168:60-67. https://doi.org/10.1016/j. cej.2010.12.034

Rezakazemi M, Shirazian S, Ashrafizadeh SN (2012) Simulation of ammonia removal from industrial wastewater streams by means of a hollowfiber membrane contactor. Desalination 285:383-392. https://doi. org/10.1016/j.desal.2011.10.030

Rezakazemi M, Ghafarinazari A, Shirazian S, Khoshsima A (2013) Numerical modeling and optimization of wastewater treatment using porous polymeric membranes. Polym Eng Sci 53:1272-1278. https://doi.org/10.1002/ pen. 23375

Rezakazemi M, Shahidi K, Mohammadi T (2014) Synthetic PDMS composite membranes for pervaporation dehydration of ethanol. Desalin Water Treat 54:1-8. https://doi.org/10.1080/19443994.2014.887036

Rezakazemi M, Khajeh A, Mesbah M (2018a) Membrane filtration of wastewater from gas and oil production. Environ Chem Lett 16:367-388. https:// doi.org/10.1007/s10311-017-0693-4

Rezakazemi M, Maghami M, Mohammadi T (2018b) High loaded synthetic hazardous wastewater treatment using lab-scale submerged ceramic membrane bioreactor. Period Polytech Chem Eng 62:299-304. https:// doi.org/10.3311/ppch.11459

Rezakazemi M, Sadrzadeh M, Mohammadi T (2018c) Separation via pervaporation techniques through polymeric membranes. In: Wilson R, George SC (eds) Transport properties of polymeric membranes. Elsevier, Amsterdam, pp 243-263. https://doi.org/10.1016/b978-0-12-809884-4.00013-6

Selvaraj V, Sakthivel P, Rajendran V (2015) Effect of ultrasound in the free radical polymerization of acrylonitrile under a new multi-site phase-transfer catalyst-A kinetic study. Ultrason Sonochem 22:265-271. https://doi. org/10.1016/j.ultsonch.2014.05.002 
Shahverdi M, Baheri B, Rezakazemi M, Motaee E, Mohammadi T (2013) Pervaporation study of ethylene glycol dehydration through synthesized (PVA-4A)/polypropylene mixed matrix composite membranes. Polym Eng Sci 53:1487-1493. https://doi.org/10.1002/pen.23406

Shirazian S, Rezakazemi M, Marjani A, Moradi S (2012) Hydrodynamics and mass transfer simulation of wastewater treatment in membrane reactors. Desalination 286:290-295. https://doi.org/10.1016/j.desal.2011.11.039

Sornalingam K, McDonagh A, Zhou JL (2016) Photodegradation of estrogenic endocrine disrupting steroidal hormones in aqueous systems: progress and future challenges. Sci Total Environ 550:209-224. https://doi. org/10.1016/j.scitotenv.2016.01.086

Sun Y, Chen Z, Wu G, Wu Q, Zhang F, Niu Z, Hu H-Y (2016) Characteristics of water quality of municipal wastewater treatment plants in China: implications for resources utilization and management. J Clean Prod 131:1-9. https://doi.org/10.1016/j.jclepro.2016.05.068

Suri RPS, Nayak M, Devaiah U, Helmig E (2007) Ultrasound assisted destruction of estrogen hormones in aqueous solution: effect of power density, power intensity and reactor configuration. J Hazard Mater 146:472-478. https://doi.org/10.1016/j.jhazmat.2007.04.072

Wojnarowicz P, Yang W, Zhou H, Parker WJ, Helbing CC (2014) Changes in hormone and stress-inducing activities of municipal wastewater in a conventional activated sludge wastewater treatment plant. Water Res 66:265-272. https://doi.org/10.1016/j.watres.2014.08.035

Wu TY, Guo N, Teh CY, Hay JXW (2012) Advances in ultrasound technology for environmental remediation. Springer, New York

Yi H, Bao X, Tang X, Fan X, Xu H (2016) Estrogen modulation of calretinin and BDNF expression in midbrain dopaminergic neurons of ovariectomised mice. J Chem Neuroanat 77:60-67

Zhang F-S, Xie Y-F, Li X-W, Wang D-Y, Yang L-S, Nie Z-Q (2015) Accumulation of steroid hormones in soil and its adjacent aquatic environment from a typical intensive vegetable cultivation of North China. Sci Total Environ 538:423-430. https://doi.org/10.1016/j.scitotenv.2015.08.067

\section{Submit your manuscript to a SpringerOpen ${ }^{\odot}$ journal and benefit from:}

- Convenient online submission

- Rigorous peer review

- Open access: articles freely available online

- High visibility within the field

- Retaining the copyright to your article

Submit your next manuscript at $\gg$ springeropen.com 